\title{
Confronting the gated community: Towards a decolonial critique of violence beyond the paradigm of war
}

\author{
Henrique Tavares Furtado* (D) \\ Department of Social Sciences, Frenchay Campus, University of the West of England, Bristol, United Kingdom \\ ${ }^{\star}$ Corresponding author. Email: Henrique.tavaresfurtado@uwe.ac.uk
}

(Received 17 June 2020; revised 9 April 2021; accepted 12 April 2021; first published online 24 May 2021)

\begin{abstract}
This article investigates the works of Dussel, Maldonado-Torres, and Mbembe as representatives of a tendency in the field of decolonial thought to assume the templates of warfare and the camp as the archetypal registers of violence in the contemporary world. Identifying this focus as the remnant of a Eurocentric vocabulary (the paradigm of war), the article proposes a shift from the language of warfare predominant in the field to a language of welfare. The article turns to the gated community (GC), instead of the camp, and the imperatives of (re)creation, instead of the logics of elimination, as new templates with which to make sense of modern/colonial violence. Moving beyond militaristic imagery, the analysis shows a form of violence that emerges as a response to the endless search for a life of convenience inside the walls of the GC. To this end, the article advances the concept of the dialect of disarrangement, the enforced but uneasy encounter between two subjectivities that inhabit the GC: the patrons (the homeowners who consume the easy life) and servants (the racialised service staff). In the GC, violence emerges in attempts to respond to this (in)convenient encounter via misrepresentations of both patrons and servants as out of their place.
\end{abstract}

Keywords: Violence; Decolonisation; Critical International Relations Theory; Race; Gated Communities; Necropolitics

\section{Introduction}

On 17 March 2020, 63-year-old Cleonice Gonçalves died at a public hospital in the small town of Miguel Pereira, Greater Rio de Janeiro. Gonçalves, a houseworker, became unwell at her workplace, an apartment in Leblon, a fashionable neighbourhood 71 miles away from the hospital where she was later admitted. Gonçalves was the first confirmed victim of Covid-19 in the state of Rio de Janeiro. ${ }^{1}$ Two weeks after her death, in an interview given to the newspaper Folha de São Paulo, Achille Mbembe argued that the global pandemic had weaponised the human body and democratised the necropolitical power to kill. Isolation, he contended, was a measure to manage the fear of death and the unknown future. In his view, the crisis exposed the unsavoury nature of capitalism and neoliberalism (or, in his words, necroliberalism) as a necropolitical system that distributes life and death opportunities unequally, discarding with ease the lives deemed to have no value. ${ }^{2}$

Mbembe's words sound prescient at the time of writing, with the coronavirus death toll exceeding 1.5 million globally and opposition to quarantine measures surpassing any level of

\footnotetext{
${ }^{1}$ Rachel Randall, 'Domestic Workers and COVID-19: Brazil's Legacy of Slavery Lives On', available at: \{https://migration.blogs. bristol.ac.uk/2020/10/27/domestic-workers-and-covid-19-brazils-legacy-of-slavery-lives-on/\} accessed 20 November 2020.

${ }^{2}$ Achille Mbembe and Diogo Bercito, 'Pandemia democratizou poder de matar, diz autor da teoria da necropolítica', available at: \{https://www1.folha.uol.com.br/mundo/2020/03/pandemia-democratizou-poder-de-matar-diz-autor-da-teoria-danecropolitica.shtml\} accessed 20 November 2020.

(C) The Author(s) 2021. Published by Cambridge University Press. This is an Open Access article, distributed under the terms of the Creative Commons Attribution licence (http://creativecommons.org/licenses/by/4.0/), which permits unrestricted re-use, distribution, and reproduction in any medium, provided the original work is properly cited.
} 
disregard for the value of human life. ${ }^{3}$ Death must run its course, we are told, so that our economy may live. The context makes it very tempting to wholesomely accept Mbembe's necropolitical vision of a world in which bodies become weapons, insecurities are addressed through isolation and segregation, and the unworthy are seen as disposable. Yet, none of these descriptions seem to apply to Gonçalves's case. The houseworker was infected by an employer who, upon returning from a leisure trip to Italy, chose to keep her long-time employee at work, in close proximity, despite experiencing the initial signs of infection. The case suggests that she was not seen as disposable or worthless, but as indispensable to her employer's life.

Critiques of violence are always warranted, but the present crisis has made them urgent. The so-called 'new normal' calls for the rethinking of old assumptions. This article contends that Mbembe's words are representative of a wider tendency in the field of Contemporary Decolonial Thought (CDT) that assumes the templates of warfare and the camp as the archetypal registers of violence in the contemporary world. The article provides a topic contribution to contemporary debates in International Relations (IR) ${ }^{4}$ and beyond, arguing against the temptation to reduce the complexity of violence to an eliminationist logic. It seeks to push the boundaries of CDT beyond the focus on warfare towards the contradictory dynamics of welfare and the reproduction of easy life. The article turns to the gated community, instead of the camp, and the imperatives of (re)creation, instead of the logics of elimination, as new templates with which to make sense of violence in the contemporary world. Moving beyond militaristic imagery, the analysis shows a form of violence that emerges as a response to the inherent contradictions of the maximisation of conveniences in the modern/colonial world (M/ $\mathrm{CW}$ ). To this end, the article advances the concept of the dialectics of disarrangement - the enforced but uneasy encounter between two subjectivities equally defined by the lived experience of life as 'out of place' - as one of the central mechanisms of violence in the GC. The article seeks to emphasise what it sees as one of the most important lessons of the current crisis: the fact that lives are put at risk not because they are disposable, but because they are essential workers.

The first part of the article analyses the works of Enrique Dussel and Nelson MaldonadoTorres, alongside Mbembe, as three exponents of the privilege attributed to the templates of warfare and the camp in CDT. This part investigates the under-explored connection between their works on violence and modern subjectivities, outlining their common rejection of the Eurocentric myth of the development of Western civilisation as the progressive pacification of violence (civility). I explain how, in their view, the modern/colonial order is founded on a genocidal logic and the regimes of apartheid inaugurated by colonial conquest and the ensuing dehumanisation of non-European lives; how far from instituting global peace, colonisation normalised the ethics and practices of warfare by moulding the subjectivity of white/European Man along the lines of a violent subject qua conqueror.

The second part describes this eliminationist logic in terms of a 'decolonial triangle of violence' (linking Conquest-Dehumanisation-Disposability). It proceeds to identify a certain paradox in this triangular logic: the fact that warfare appears as the universal currency/language, both denounced as the epistemological and practical basis of modern/colonial violence and

\footnotetext{
${ }^{3}$ World Health Organization, 'WHO Coronavirus Disease (COVID-19) Dashboard', available at: \{https://covid19.who.int/? gclid=Cj0KCQiAzsz-RCCARIsANotFgOC2fPj77t7hGEfhFTBmGJqu_BRpcC-PPGsBJeGIJKh-h8cLWI-67MaAuPEALw_wcB $\}$ accessed 20 November 2020.

${ }^{4}$ The theme of decolonisation has been popularised in the last decade. See Kimberly Hutchings, 'Decolonizing global ethics: Thinking with the pluriverse', Ethics and International Affairs, 33:2 (2019), pp. 115-25; Robbie Shilliam, 'Decolonising the grounds of ethical inquiry: A dialogue between Kant, Foucault and Glissan', Millennium: Journal of International Studies, 39:3 (2011), pp. 649-65; Karen Tucker, 'Unraveling coloniality in International Relations: Knowledge, relationality, and strategies for engagement', International Political Sociology, 12:3 (2018), pp. 215-32; Cristina Rojas, 'Contesting the colonial logics of the international: Toward a relational politics for the pluriverse', International Political Sociology, 10:4 (2016), pp. 369-82; Louiza Odysseos, 'Prolegomena to any future decolonial ethics: Coloniality, poetics and "being human as praxis"', Millennium: Journal of International Studies, 45:3 (2017), pp. 447-72; Priya Dixit, 'Decolonial strategies in world politics: C. L. R. James and the writing and playing of cricket', Globalizations, 15:3 (2018), pp. 377-89; Lucy Taylor, 'Decolonizing International Relations: Perspectives from Latin America', International Studies Review, 14:3 (2018), pp. 386-400.
} 
employed as the means of its critique. I explain this paradox as an unfinished attempt to subvert the Eurocentric dichotomy between peace/war, successfully flipping its central terms (showing peace to be grounded on an endless war) but never truly dismissing its centrality.

The final part proposes an exercise of epistemic disobedience, offering an alternative to this deadlock. This part engages with the literature on gated communities and critiques of (racial) capitalism to introduce the new template of the GC and the dialectics of disarrangement. This part reshapes the decolonial triangle of violence by amending its central terms (Conquest-Dehumanisation-Disposability) and anchoring them in a new triad (ConvenienceDisarrangement-Irreplaceability). It qualifies the image of White/European Man by posing the GC as home to a less imposing mode of subjectivity: not a conqueror but the insecure subjectivity of the 'white, but not quite', who disavows his world and is forced to endure the proximity of the racialised servants he despises. His enjoyment of the easy life (maximisation of convenience) is troubled by the following realisations: that his easy life would collapse in complete isolation; that his racialised servants are not disposable but irreplaceable; and that his servants are not his radical others, but unescapably his equals.

\section{The colonial clash of subjectivities}

In the vast universe of decolonial critiques of violence, the names of Dussel, ${ }^{5}$ Maldonado-Torres, ${ }^{6}$ and Mbembe $^{7}$ stand out. Pairing a concern for the phenomenology of colonial oppression with a critique of Eurocentric myths, their work provides a fundamental framework for revealing the hidden violence of modernity. Writing at different times and from different backgrounds, they nonetheless reach a significant common ground: a critique of Eurocentrism they identify in the opposition between violence (understood as a sign of barbarism) and civilisation (understood as the telos of development). Their work begins by rejecting traditional readings of the unfolding of civilisation as the progressive taming of violence and barbarism within the borders of Europe. ${ }^{8}$ They see in this narrative, and in all representations of violence as foreign to the European modern ethos, the workings of a mythology ${ }^{9}$ or fantasy: ${ }^{10}$ a (mis)representation of the past that hides its foundational violence and legitimises systems of subordination in the present.

Following in the footsteps of previous postcolonial/decolonial works, they endeavour to show what Lugones described as modernity's 'intimate relation with violence'. ${ }^{11}$ They share a commitment to reveal how the development of modern civilisation is not only haunted, but was essentially preconditioned by its acts of violence. ${ }^{12}$ To this end, their critiques of modern violence go back to the historical experience of colonial conquest. ${ }^{13}$ Disobeying the Eurocentric episteme,

\footnotetext{
${ }^{5}$ Enrique Dussel, 'World-system and “trans”-modernity', Nepantla: Views from South, 3:2 (2002), pp. 221-44; Enrique Dussel, 1492: El encubrimiento del otro: hacia el origen del mito de ma modernidad (La Paz: Plural Editores, 1994); Enrique Dussel, Filosofía de la liberación (Ciudad de Mexico: FCE, 2011).

${ }^{6}$ Nelson Maldonado-Torres, 'Transdisciplinaridade e decolonialidade', Sociedade e Estado, 31:1 (2016), pp. 75-97; Maldonado-Torres, Against War; Nelson Maldonado-Torres, 'On the coloniality of being: Contributions to the development of a concept', Cultural Studies, 21:2-3 (2007), pp. 240-70.

${ }^{7}$ Achille Mbembe, On the Postcolony (Berkley, CA and London: University of California Press, 2001); Achille Mbembe, Necropolitics (Durham, NC: Duke University Press, 2019); Achille Mbembe, Critique of Black Reason (Durham, NC: Duke University Press, 2017).

${ }^{8}$ Norbert Elias, The Civilizing Process (Oxford, UK: Blackwell Publishing, 1982); Anthony Giddens, The Nation State and Violence: Volume Two of a Contemporary Critique of Historical Materialism (Cambridge, UK: Polity Press, 1985); For an inversed version of the argument of civility that nonetheless maintains the modernising gaze, see Pierre Clastres, $L a$ archéologie de la violence: La guerre dans les sociétés primitives (s.l.: Éditions de L’Aube, 2013).

${ }^{9}$ Dussel, 1492: El encubrimiento del otro.

${ }^{10}$ Mbembe, Critique of Black Reason.

${ }^{11}$ María Lugones, 'Toward a decolonial feminism', Hypatia, 25:4 (2010), pp. 742-59.

${ }^{12}$ Mbembe, Necropolitics; Mbembe, On the Postcolony.

${ }^{13}$ Dussel, 1492: El encubrimiento del otro.
} 
their work analyses the rise of the modern world as a historical process that cannot be separated from the violence of European colonialism. Instead of triggering the forward march of the global democratic revolution, the clash between conquerors and conquered inaugurated an unequal system. A world whereby the emancipation of the former (Europe) depended on the devaluation, enslavement, or annihilation of the latter (the slave, the Third World, Africa).

Dussel and Maldonado-Torres explicitly raise colonialism as opposed to the European enlightenment as the inaugural event of modernity. For them, it is the concrete historical experience of the conquest, enslavement, and brutal annihilation of non-European peoples, worlds, and cosmologies that constitutes the conditions of possibility for the rise of Europe and the modern world. ${ }^{14}$ They link the 'pacification' of European nation states to a history of military expansion and violent rule overseas, beginning with the subjugation and dissolution of Al-Andalus, Anáhuac, and Tawuantinsuyu. ${ }^{15}$ Similarly, Mbembe emphasises that the so-called 'civilisation of mores ${ }^{16}$ was entirely conditioned by the appearance of slavery and new 'forms of wealth accumulation and consumption inaugurated by the colonial adventure. ${ }^{17}$ He contrasts the development of democracy across the Atlantic with the incredible tolerance shown 'for a certain political violence' ${ }^{18}$ and the incorporation of 'forms of brutality into their culture'. ${ }^{19}$

Importantly, colonial conquest is more than a historical coincidence. Conquest provides two sine qua non conditions for the emergence of the M/CW: the racialised fantasy of European superiority and the experience of mastery over the world. ${ }^{20}$ Effectively, colonial conquest and the rise of a Euro-centred economic system of global proportions constituted a new reality in the European imaginary: the de facto acquisition of dominus mundi, the experience of global rule/domination previously reserved for God and the church. The establishment of empires on which the sun never set provoked a fundamental change to the ways in which individuals related to themselves and their place in the world (the question of subjectivity). The global and Euro-centred system inaugurated by colonialism broke with the inalienable distance envisioned by the medieval order between Man (a limited being) and God (an omnipresent and omnipotent deity). ${ }^{21}$ More than the addition of land, cheap labour, and raw materials to European crowns, colonialism produced an exponential change in the sense of self-importance attributed to the (European) Man. The use of the masculine form is intentional throughout this work, emphasising the patriarchal nature of domination and exploitation in the $\mathrm{M} / \mathrm{CW}$, predicated on the devaluation of femininity and the violation of feminine or effeminate bodies. ${ }^{22}$

For Dussel and Maldonado-Torres, it is this concrete historical experience of replacing God in practice $^{23}$ that conditioned modern attempts to systematise God's 'redundancy' in theory. They refuse to see as coincidental the fact that modern science, epistemology, and phenomenology appeared from the sixteenth century onwards in the societies of the colonial centre. They connect the concerted intellectual effort to clarify the limits of what can be known to the colonial/imperial practice of differentiation between the subjects who can know (who are endowed with reason) and those who must be known (objectified, classified, studied). In the foundational works of

\footnotetext{
${ }^{14}$ Enrique Dussel, 'Meditações Anti-Cartesianas sobre a Origem do Anti-Discurso Filosófico da Modernidade', in Boaventura de Sousa Santos and Maria Paula Meneses (eds), Epistemologias do Sul (Coimbra: Almedina, 2009), pp. 283336; Maldonado-Torres, 'On the coloniality of being'; Dussel, 1492: El encubrimiento del otro.

${ }^{15}$ Dussel, 1492: El encubrimiento del otro.

${ }^{16}$ Mbembe, Necropolitics, p. 19.

${ }^{17}$ Ibid.

${ }^{18}$ Ibid., p. 17.

${ }^{19}$ Ibid.

${ }^{20}$ Dussel, 1492: El encubrimiento del otro; Maldonado-Torres, 'On the coloniality of being'.

${ }^{21}$ Maldonado-Torres, 'On the coloniality of being'; Maldonado-Torres, Against War.

${ }^{22}$ Silvia Frederici, Caliban and the Witch: Women, the Body and Primitive Accumulation (New York, NY: Autonomedia, 2004); Lugones, 'Toward a decolonial feminism'; Rita Laura Segato, La critica a la colonialidad en ocho ensayos y una antropología por demanda (Buenos Aires: Prometeo Libros, 2015).

${ }^{23}$ Dussel, 1492: El encubrimiento del otro; Maldonado-Torres, Against War.
} 
modern philosophy, Dussel and Maldonado-Torres hear the more or less explicit echoes of colonial difference. ${ }^{24}$

In his prime example, Dussel weaves a fundamental connection between the Cartesian ego cogito and the fact of conquest. For him, Descartes' conception of the thinking being as the condition of possibility of knowledge, independent of the materiality of his body and surroundings, is unthinkable without the 'transformation' of the European Man into an omnipresent and omnipotent being (empire). ${ }^{25}$ Dussel sees in the Cartesian ego cogito (and later in Hegel, Kant, and Heidegger) the legitimisation of the subjectivity of the conqueror, a mode of being authorised to speak about, and adjudicate, on anything and anybody, anywhere.

Dussel is by no means alone in criticising the universalisation of European provincialism as a trademark of modernity, ${ }^{26}$ but he provides a genuine twist to a well-known critical trope. What is at stake here is not a critique of the Cartesian ego cogito as expressing imperial drives to classify and control the subjugated others of Europe, ${ }^{27}$ but the very conditions of possibility of such reasoning. Dussel emphasises that the Cartesian leap of faith can only emerge in the realm of thinkable possibilities once the experience of universal domination has been confirmed, lived, and interiorised as a natural fact. ${ }^{28}$ The central lesson is that one can only think of the ego cogito (I think, therefore I am) from within the lived experience of the ego conquiro (I conquer, therefore I am). ${ }^{29}$

The historical birth of the subject qua conqueror is further analysed by Maldonado-Torres as a central cog in the mechanism of modern/colonial violence. ${ }^{30}$ According to Maldonado-Torres, the transgression of the abyss separating European Man from God (which he describes as transontological difference) instils in modern subjectivities two profound senses of scepticism. On one hand, we have the well-known scepticism showed by the Cartesian subject, who doubts his thoughts, sensations, and very existence only to realise that the act of doubting is itself the most secure foundation for knowledge (one cannot doubt if one is not).

The gap between God and European Man (ego conquiro) can only be closed at the expense of alterity. The fact of conquest and the erasure of trans-ontological difference produce a new figure (the non-European) who is supposed to function, quite literally, as the symbolic refuse in the deification of European Man. In the M/CW, non-Europeans become the embodied repository of a series of human flaws (for example, sinfulness, laziness, immaturity, irrationality, hatred), artificially dissociated from the elevated image of the ego conquiro. ${ }^{31}$ It is this accumulation of negative markers that supports the myth of European superiority by translating multiple experiences of subalternity around the world under the pretence of an essential sub-alterity: ${ }^{32}$ the naturalisation of inequalities between colonisers and colonised as sub-ontological differences 'between Being and what lies below Being, ${ }^{33}$

This purgative process has tremendous consequences for the inter-subjective relations between colonisers and colonised. Those whom Frantz Fanon called the wretched or damnés, ${ }^{34}$ the

\footnotetext{
${ }^{24}$ Walter Mignolo, 'The geopolitics of knowledge and the colonial difference', South Atlantic Quarterly, 101:1 (2002), pp. 57-96.

${ }^{25}$ Dussel, 'Meditações Anti-Cartesianas'.

${ }^{26}$ Dipesh Chakrabarty, Provincializing Europe: Postcolonial Thought and Historical Difference (Princeton, NJ: Princeton University Press, 2009).

${ }^{27}$ Abdul JanMohamed, 'The economy of Manichean allegory: The function of racial difference in colonialist literature', Critical Inquiry, 12:1 (1985), pp. 59-87; Edward W. Said, Orientalism: Western Conceptions of the Orient (New York, NY: Pantheon Books, 1978).

${ }^{28}$ Dussel, Filosofía de la liberación.

${ }^{29}$ Dussel, 'Meditações Anti-Cartesianas'; Maldonado-Torres, 'On the coloniality of being'.

${ }^{30}$ Maldonado-Torres, 'On the coloniality of being'.

${ }^{31}$ For a similar view, see Grada Kilomba, Memórias da Plantação: Episódios de Racismo Quotidiano (Lisbon: Orfeu Negro, 2019).

${ }^{32}$ Maldonado-Torres, Against War.

${ }^{33}$ Maldonado-Torres, 'On the coloniality of being', p. 254.

${ }^{34}$ Frantz Fanon, The Wretched of the Earth (New York, NY: Grove Press, 1963).
} 
colonised, are not seen as the coloniser's others. Effectively, the subject qua conqueror has no 'others'; he inhabits what Césaire described as a world of 'thingification', ${ }^{35}$ where the value of things and beings is primarily defined by their replaceability. The ego conquiro lives as the Heideggerian dasein, ${ }^{36}$ surrounded by tools or servants/slaves who are not seen as (fully) humans or individuals, but as standardised objects that remain at his disposal. Unlike the European Man, the damnés are never recognised as individuals, but only members of a mass whose distinctiveness lies solely in what they lack in relation to the ego conquiro. ${ }^{37}$ They are relegated to live their lives in the 'zones of non-being', ${ }^{38}$ their possibilities foreclosed by their default position in modern/colonial order. They become 'symbols of a vegetative, limited state ... powerfully possessed by emptiness, for whom the negative had ended up penetrating all moments of existence'. ${ }^{39}$

This symbolic play of associations and disassociations that produces violent intersubjective relations cannot hold without the fantasy of race. Both Maldonado-Torres and Dussel (in his later works) engage with the concept of race via Aníbal Quijano, who situates race (alongside labour) as the central axis of articulation of forms of domination and exploitation in the M/ CW. ${ }^{40}$ In Quijano, race appear as a classificatory principle linking fictive groups (ethnicities) to specific positions in a complex global division of labour (and, we should add, also citizenship). This principle of classification, whose function lies in naturalising unequal relations of servitude, did not end with formal processes of decolonisation (hence, Quijano's choice for the word coloniality). ${ }^{41}$ Race has no static meaning, but it does seem to have an enduring function: the provision of a vocabulary with which to translate the inequality between colonisers and colonised in terms of a difference in degrees of humanity. ${ }^{42}$

Mbembe does not engage directly with Quijano but shows a similar understanding. Race is, for him, the 'ultimate sign of the dissimilar' under modernity; a fantasy that propels the so-called West into the 'centre of the earth and the birthplace of reason, universal life, and the truth of humanity'. ${ }^{43}$ Race legitimises the circular logics of power and sovereignty in the colonies, ${ }^{44}$ structuring the relationship between Europeans and the colonised around 'the very negation of the idea of ... common humanity'. ${ }^{45}$ For Maldonado-Torres, the colonial 'misanthropic skepticism, ${ }^{46}$ or the suspension of any human semblance between the colonisers and the colonised, pre-exists and conditions modern methodological scepticism. Once again, this essential denial is what conditions the organisation of the colonial world by naturalising its inherently unequal order. It is the glue that holds the amorphous and empty idea of this non-subject (the damné) together, imprinting on the skin of the wretched multiple, contradictory, and baseless flaws associated with the Third World, ${ }^{47}$ the negro, or the African. ${ }^{48}$

Modern promises of emancipation appear in a different light when contrasted with its underlying, colonial clash of subjectivities. Colonial conquest provided Europe with dreams of

\footnotetext{
${ }^{35}$ Césaire, Discourse on Colonialism, p. 42.

${ }^{36}$ Maldonado-Torres, 'On the coloniality of being'.

${ }^{37}$ Frantz Fanon, Black Skin, White Masks (London, UK: Pluto Press, 2008); Mbembe, On the Postcolony.

${ }^{38}$ Fanon, The Wretched of the Earth.

${ }^{39}$ Mbembe, Critique of Black Reason, p. 11.

${ }^{40}$ Aníbal Quijano, 'Questioning "race”, Socialism and Democracy, 21:1 (2007), pp. 45-53; Aníbal Quijano and Immanuel Wallerstein, 'Americanity as a concept, or the Americas in the modern world-system', International Social Science Journal, 134 (1992), pp. 583-91.

${ }^{41}$ Anibal Quijano, 'Colonialidad del poder y clasificacion social', Journal of World-Systems Research, 6:2 (2000), pp. 34286.

${ }^{42}$ Maldonado-Torres, 'On the coloniality of being'.

${ }^{43}$ Mbembe, Critique of Black Reason, p. 11.

${ }^{44}$ Mbembe, On the Postcolony.

${ }^{45}$ Mbembe, Critique of Black Reason, p. 54; Maldonado-Torres, 'On the coloniality of being', p. 245.

${ }^{46}$ Maldonado-Torres, 'On the coloniality of being', p. 245.

${ }^{47}$ Dussel, 1492: El encubrimiento del otro.

${ }^{48}$ Mbembe, Critique of Black Reason.
} 
masterless societies and life without scarcity that would come to reshape European progressive thought in profound ways. ${ }^{49}$ But it also enacted the co-optation of such dreams by normalising a 'master morality of dominion and control'. ${ }^{50}$ Through conquest, the newly emancipated subject becomes free by becoming a master shaped in the image of the divine. His lived experience of unlimitedness necessarily blurs the lines separating the enjoyment of freedom from the exercise of power (the fulfilment of his potentialities) as the denial of rights to others. ${ }^{51}$ Because, in essence, the ego conquiro can only truly emancipate himself in an environment that does not recognise alterity as a tangible limit to his desire. His emancipation is an extractivist process, to use Ramón Grosfoguel's formulation, mining the lands, bodies, lives, and cosmologies of the damné in the search for value, pleasure, and a sense of distinctiveness. ${ }^{52}$ And as any extractive process, it also leaves deep marks in the landscapes of modern/colonial societies, drawing a line alongside which (in)security is distributed and accumulated at very visible ends. The fantasy of race plays no small part here, functioning as the operational principle of this distribution. The racial mark invites the humiliation and violation of racialised bodies, 'negatively marked as dispensable', ${ }^{53}$ anchoring the modern promise of emancipation on a tacit promise of impunity.

\section{The triangle of violence: Conquest-dehumanisation-dispensability}

As Silvia Rivera Cusicanqui and Freya Schiwy remind us, it is important to 'understand they ways decolonization pushes against the building blocks of coloniality and where, at times inadvertently, decolonization recreates these'. ${ }^{54}$ The works of Dussel, Maldonado-Torres, and Mbembe certainly push some important blocks. Their joint refusal of the Eurocentric myth of civility is an act of epistemic disobedience that, at least in Dussel's case, is strongly committed to a praxis of commiseration: ${ }^{55}$ the preferential option for the perspectives and the lived experiences of the oppressed. This commitment is not a charitable act, but a decision born of the acute awareness that the oppressed stand in a privileged position; living in the space of colonial difference, they are best suited to find 'transmodern' alternatives to the present violent order. The effort to uncover the lives and worldviews suppressed by the forward march of modernity/coloniality is, above all, an effort to learn from these silenced voices, anchoring the practice of epistemic disobedience in the margins of the $\mathrm{M} / \mathrm{CW}$.

A closer examination of their work reveals a certain vocabulary that is strikingly at odds with this act of epistemic disobedience. At the core of their critical project, the concept of violence plays an ambiguous role. On one hand, the denunciation of modernity/colonisation as a violent historical process is a fundamental part of the decolonial rejection of narratives of civility and pacification. On the other, this very act of denunciation limits the extent of epistemic disobedience at play by mobilising representations of violence from within the Eurocentric tradition (the language of warfare and image of the camp). To put it simply, it is not always clear at which point the naming of modern/colonial violence ends, and the reproduction of the modern/colonial vocabulary begins.

The concept of violence is anything but straightforward. To being with, there is no consensus about what violence means, and little agreement on the essential characteristics that make

\footnotetext{
${ }^{49}$ Frederici, Caliban and the Witch; Hannah Arendt, On Revolution (London, NY: Penguin Books, 1990).

${ }^{50}$ Maldonado-Torres, Against War, p. 2.

${ }^{51}$ Mbembe, Necropolitics.

${ }^{52}$ Ramón Grosfoguel, 'Del "extractivismo económico" al "extractivismo epistémico" y al "extractivismo ontológico": Una forma destructiva de conocer, ser y estar en el mundo', Tabula Rasa, 24 (2016), pp. 123-43.

${ }^{53}$ Maldonado-Torres, 'On the coloniality of being', p. 254.

${ }^{54}$ Silvia Rivera Cusicanqui, 'Ch'ixinakax Utxiwa: A reflection on the practices and discourses of decolonization', South Atlantic Quarterly, 111:1 (2012); Freya Schiwy, 'Decolonization and the question of subjectivity: Gender, race, and binary thinking', Cultural Studies, 21:2-3 (2007), pp. 271-94 (p. 273).

${ }^{55}$ Dussel, Filosofía de la liberación.
} 
something violent. The adjective 'violent' is often attached to numerous, disparate phenomena, evidencing a polysemic and fluid nature of the everyday and academic perceptions of the phenomenon. ${ }^{56}$ The importance attributed to the fact of conquest and the clash of subjectivities profoundly shapes the meaning of violence in Dussel, Maldonado-Torres, and Mbembe. More than interpersonal acts of injury, the experience of injustice, or the instrumental use of force, ${ }^{57}$ violence refers to the different degrees of elimination of the non-European world that are required by the modern promise of emancipation. By elimination I mean the more or less literal erasure of the lives, knowledges, and cosmologies of non-Europeans that seeks to purify the M/CW from perceived signs of difference (degeneration). For Dussel, Maldonado-Torres, and Mbembe, modern/colonial violence operates through multiple acts, institutions, and symbolic processes that at best impose systems of exclusions and separation (apartheid), and at worst pave the way for indiscriminate mass killing.

It is fair to say that, in their work, the elimination/erasure of the colonised assumes the form of a triangle: Conquest-Dehumanisation-Dispensability (Figure 1). Colonial conquest produces two phenomena that showcase an 'intimate relationship' between violence and modernity: First, the constitution of the modern, emancipated subject as a subject qua conqueror, an existence whose emancipation depends on the unlimited extraction of value, pleasure, and worth from his surroundings. Second, the fabrication of racialised myths of civility (the framing of the conquest as a moment of 'pacification') and superiority (the assumption of European Man as the measure of all things). At the core of these two processes lies the fantasy of race (the translation of difference as ontological deficiency). Race resignifies colonial conquest as a foretold fact, inscribed in the very ontology of the ego conquiro (a superior being). And by introducing systems of differentiation or intensifying pre-existing ones (such as the varna-jati scheme in India, reworked into the modern caste system $)^{58}$ the act of conquest naturalised the dehumanisation of the colonised either in absolute or in gradational terms. Racial/colonial difference works by marking the bodies, lives, and cosmologies of the colonised, particularly those at the very bottom of this hierarchical system, as dispensable (as things that, having no further use, can be tossed away without further thought). To use Grosfoguel's words, this triangular logic of violence produces the conditions for the constant slippage between the ego conquiro and a genocidal 'yo extermino, luego existo [I exterminate, therefore I am (ego extermino)]'.59

Dussel, Maldonado-Torres, and Mbembe are not the only ones, or even the first, to see modern/colonial violence through the lenses of elimination/erasure. The theme of elimination (incorporating the meanings of negation, exclusion, and violation of the colonised) are inscribed in a longstanding tradition of activism and scholarship denouncing the genocidal nature of modernity/coloniality. As early as 1951, American civil rights activists presented the petition We Charge Genocide to the United Nations, condemning the lynching and segregation of black Americans as an instance of genocide, making use of the then fresh language of the Genocide Convention (1948). The year before, Aimé Cesáire had published Discours sur le Colonialisme in Paris, making public his famous comments on the Nazi Holocaust. For Cesáire, the crimes

\footnotetext{
${ }^{56}$ Willem Schinkel, Aspects of Violence: A Critical Theory (Basingstoke, UK: Palgrave Macmillan, 2000); Michel Wieviorka, Violence: A New Approach (London, UK: Sage Publications, 2009); Elizabeth Anne Stanko, The Meanings of Violence (London, UK: Routledge, 2003).

${ }^{57}$ Hannah Arendt, On Violence (New York and London: Harcourt Brace Jovanovich, 1970); Vittorio Bufacchi, 'Two concepts of violence', Political Studies Review, 3:2 (2005), pp. 193-204.

${ }^{58}$ The word 'caste' (from the Portuguese/Spanish casta, meaning a class of plants or animals) was first used in reference to the system of social differentiation in India by the Portuguese factor for the Malabar coast, Duarte Barbosa in the sixteenth century. The caste system later became one of the pinnacles of indirect rule during the British Raj, enabling the unequal distribution of privileges across different social groups. See Francisco Bethencourt, Racisms: From the Crusades to the Twentieth Century (Princeton, NJ: Princeton University Press, 2013).

${ }^{59}$ Ramón Grosfoguel, 'Racismo/Sexismo epistémico, universidades occidentalizadas y los cuatro genocidios/epistemicidios del largo siglo XVI’, Tabula Rasa, 19 (2017), pp. 31-58 (p. 39).
} 


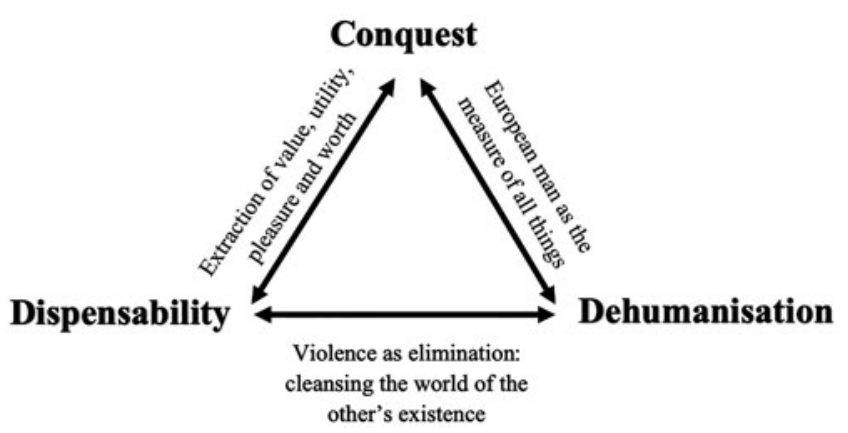

Figure 1. The decolonial triangle of violence.

committed by the Nazi regime in Europe had been preceded and instructed by centuries of similar forms of violence in colonial settlements. In his understanding, the Holocaust was not rendered horrific because it constituted an offense to the very idea and essence of humanness, as Hannah Arendt would have it. ${ }^{60}$ The Holocaust was experienced as grotesque because, for the first time, the old colonial procedures that 'had been reserved exclusively for' ${ }^{61}$ the victims of European colonialism were employed on Europeans themselves.

From Cesáire onwards, the category of genocide and the image of the Holocaust have featured in numerous decolonial writings, functioning as the extreme reminder that colonisation presupposes the (more or less literal) negation of colonised lives. ${ }^{62}$ In a sense, Dussel, Maldonado-Torres, and Mbembe follow in Cesáire's footsteps, seeing genocide as the ultimate consequence of the link between Conquest-Dehumanisation-Dispensability. It is at this point that their critiques of modern/colonial violence are infused with a certain ambiguity, the same ambiguity that characterised the efforts of civil rights activists in the 1950s: the difficulty of translating the phenomenon of violence under racialised oppression in the vocabulary of a Eurocentric/racist order. In the end, their critique of modern/ colonial violence remains entangled in a language of warfare so often used to represent extreme violence in the Western tradition. This creates a more than uncomfortable fact; whatever 'transmodern' alternatives their theory helps to build, are built on solid Eurocentric foundations.

Dussel begins his Philosophy of Liberation (1977) by remarking that, within the structure of Western domination 'la guerra es el origen de todo [war is the origin of everything]'. ${ }^{63}$ The belligerent foundations of the European world made colonisation into 'un choque devastador, genocida, absolutamente destructor del mundo indígena [a devastating, destructive, and genocidal shock for the indigenous world]'. ${ }^{64}$ For Maldonado-Torres, modern/colonial violence is deeply embedded in what he sees as a specifically modern rendition of the paradigm of war. Drawing on Levinas's critique of the philosophy of Hitlerism, he attributes the logic of elimination/erasure of the damnés to the normalisation of 'a way of conceiving humanity, knowledge, and social relations that privileges conflict or polemos ${ }^{65}$ The extreme negation of the damnés' existence is connected to 'the celebration of the reduction of the singularity of individual entities and subjects to the generality of the concept'. ${ }^{66}$ What Maldonado-Torres does here is to weave a central

\footnotetext{
${ }^{60}$ Hannah Arendt, The Human Condition (Chicago, IL: The University of Chicago Press, 1998).

${ }^{61}$ Césaire, Discourse on Colonialism, p. 36.

${ }^{62}$ Frantz Fanon, A Dying Colonialism (New York, NY: Grove Press, 1965); Gloria Anzaldúa, Borderlands/La Frontera (San Francisco, CA: Aunt Lute Books, 1987); Fanon, The Wretched of the Earth; Grosfoguel, 'Del "extractivismo económico"'; Walter Mignolo, The Idea of Latin America (Oxford, UK: Blackwell Publishing, 2005); Arturo Escobar, 'Beyond the Third World: Imperial globality, global coloniality and anti-globalisation social movements', Third World Quarterly, 25:1 (2004), pp. 207-30.

${ }^{63}$ Enrique Dussel, Filosofía de la liberación (Ciudad de México: FCE, 2011), p. 17.

${ }^{64}$ Dussel, 1492: El encubrimiento del otro, p. 66.

${ }^{65}$ Maldonado-Torres, 'Against war', p. 3.

${ }^{66}$ Ibid.
} 
connection between (metaphysical or epistemological) violence, ${ }^{67}$ the elimination of accidental or non-essential features from the definition of what exists, and the elimination of non-essential or dispensable beings (the damnés) from the foundations of the Eurocentric polis. Just as the colour of a pen (whether it is blue or green) has no bearing in its definition (what makes a pen a pen), the 'coloured' bodies of the colonised have no place in the perfect vision of the polis. To reach the perfect understanding of what a pen is, one must eliminate all its accidental/non-essential features, such as colour. The singularities of existing pens, if you may, are negated for the construction of an abstract sense of generality (the theory of what a pen is). The search for perfection becomes therefore indistinguishable from these moments of elimination/negation, configured as the cleansing of impurities that stand in the way of a fulfilling experience of the ideal. The genocidal moment is inscribed in this sequence, as the ' $\mathrm{t}$ ] he hyperbolic expression of coloniality', ${ }^{68}$ representing 'the paroxysm of the ego cogito' ${ }^{69}$ as a being that 'exists alone." 70

Mbembe's work is also exemplary of the privilege attributed to representations of violence as emerging from the logics of warfare and genocide. His very choice of framing his analysis of sovereign power in terms of a necropolitics, where 'the political takes as its primary and absolute objective the enemy's murder"71 and power is exercised as the 'right to kill', ${ }^{72}$ is very illustrative. Perhaps no other categories figure as prominently in his denunciation of violence in the (post) colonial world as the concept of exception, the principle of destruction, and the model of the camp. $^{73}$ Expanding on Agamben's interpretation of Foucault, via a complex mix of Schmitt, Bataille, and Fanon's anticolonial critique, Mbembe sees the exception (the decision that guides the transgression of moral and legal prohibitions) as one of the central elements of the political order inaugurated by the experience of European colonialism. ${ }^{74}$

Following Césaire's analysis, Mbembe detaches the exception (and the death camp as its extreme expression) from its common associations with totalitarianisms and the Nazi regime, making it into the generalisable form of necropolitical sovereignty in modern times. Moving beyond the horrors of the mid-twentieth century, he identifies the workings of the exception in the very beginnings of what we can call the M/CW.

For him, colonisation constituted the (post)colony as the negative of the image of European polities in the modern symbolic order. In this inverted world, intersubjective relations were not based on the possibility of communal life, but on fear, the proclaimed necessity of apartheid, and violent fantasies of annihilation. He sees 'the plantation world' as a pure 'manifestation of the state of exception': ${ }^{75}$ a zone 'where the controls and guarantees of judicial order can be suspended" 76 and "peace" is more likely to take on the face of a "war without end". 77

For Mbembe, the integrity and wholeness of the societies instituted by conquest are always troubled and transgressed by the framing of intersubjective relations as potential relations of enmity. Whoever takes on the role of the subaltern (or the sub-alter, to use Maldonado-Torres's terminology) in the modern world is seen as a potential risk, someone whose very 'existence' is perceived as 'an attempt on my life, as a mortal threat or absolute danger. ${ }^{78}$ Pervaded by

\footnotetext{
${ }^{67}$ For the definitions of metaphysical and epistemological violence, see Jacques Derrida, Writing and Difference (London, UK: Routledge, 2001); Gayatri Chakravorty Spivak, 'Can the subaltern speak?', in Cary Nelson and Lawrence Grossberg (eds), Marxism and the Interpretation of Culture (Basingstoke, UK: Palgrave Macmillan, 1988), pp. 271-312.

${ }^{68}$ Maldonado-Torres, 'On the coloniality of being', p. 247.

${ }^{69}$ Ibid.

${ }^{70}$ Ibid.

${ }^{71}$ Mbembe, Necropolitics, p. 66.

${ }^{72}$ Ibid. p. 70.

${ }^{73}$ Mbembe, Necropolitics.

${ }^{74}$ Mbembe, Critique of Black Reason.

${ }^{75}$ Achille Mbembe, 'Necropolitics', Public Culture, 15:1 (2003), pp. 11-40 (p. 22).

${ }^{76}$ Ibid., p. 24.

${ }^{77}$ Ibid., p. 23.

${ }^{78}$ Ibid., p. 72.
} 
their fictionalised accounts of internal enemies, these modern societies of enmity constantly nurture and are nurtured by the paranoid fear of an imminent (race) war. In this normalised state of exception, the fantasy of the annihilation of the other as an internal enemy (the principle of destruction) becomes the only possible means to ensure the security of oneself (the principle of life). Echoing Fanon, Mbembe sustains that ' $\mathrm{t}]$ he colonial process always revolved around a genocidal drive ... it was always there, in a latent state. ${ }^{79}$

At this point one explanation is needed. The violence of the colonialism is an undisputable reality. The fact that the M/CW was built and is continuously rebuilt with the blood of the 'conquered' is a fact that I have no intention of problematising. My concern here is rather to question the focus on warfare as paradigmatic, as providing the logics, vocabulary, and metaphors for all forms that violence may take in the contemporary world. ${ }^{80}$ Put it differently, my argument is that the triangular relationship between Conquest-Dehumanisation-Dispensability remains incomplete as long as it is still embedded primarily in this Eurocentric template. A decolonial reading of violence must be followed by a deeper investigation of the ways in which violence is operationalised beyond the tropes of warfare and death camps, which is the main aim of this article.

The following section does not propose a critique of the scholars discussed here, as much as a suggestion for deepening and complementing their reflections. My argument is that the decolonial triangle (see Figure 1) can be expanded and qualified with two important modifications. First, I propose a shift from a template of violence that takes the paradigm of war and the figure of the camp as the measure of violent relations (predicated on the logics of elimination) towards the prism of the gated community. Second, I suggest a reworking of the colonial clash of subjectivities not as a clash between superhuman conquerors and the subhuman conquered but as a constant dialectical encounter between two subjectivities equality defined by radically different experiences of disarrangement.

\section{The gated community (GC) and the dialects of disarrangement}

Turning to gated communities (also known as condomínios fechados in Brazil and security parks or villages in South Africa) as the source of new conceptualisations of violence might seem like a detour. The proliferation of 'residential areas with restricted access in which normally public spaces are privatized ${ }^{\prime 81}$ as a popular lifestyle choice of upper/middle-class urbanites in the 1980-90 decade also led to the mobilisation of war metaphors. The global boom in gated communities, high-rise condominiums, and privatised walled neighbourhoods ${ }^{82}$ was quickly explained with reference to the image of the urban fortress, as a sort of neo-medievalist turn. ${ }^{83}$ They were seen as 'security developments with ... walls or fences, and controlled entrances ...

\footnotetext{
${ }^{79}$ Mbembe, Necropolitics, p. 128.

${ }^{80}$ For other examples within CDT, see Arturo Arias, 'Violence and coloniality in Latin America: An alternative reading of subalternization, racialization and viscerality', in Marta Araújo and Silvia Maeso (eds), Eurocentrism, Racism and Knowledge: Debates on History and Power in Europe and the Americas (Basingstoke, UK: Palgrave Macmillan, 2015), pp. 47-64; Santiago Castro-Gómez, La hybris del punto cero: Ciencia, raza e ilustración en la Nueva Granada (1750-1816) (Bogotá: Siglo XIX, 2005); Rita Laura Segato, La guerra contra las mujeres (Madrid: Traficantes de sueños, 2016).

${ }^{81}$ Edward J. Blakely and Mary Gail Snyder, Fortress America: Gated Communities in the United States (Washington, DC: Brookings Institution Press, 1997), p. 2.

${ }^{82} \mathrm{I}$ am aware that I am bundling different concepts together here, but I am not interesting in producing a typology of different real estate developments. For reasons that will become clear later, this article uses the terms gated community, walled private neighbourhoods, and urban enclaves/enclosures as coterminous. A typology of enclavisaiton can be found in Peter Marcuse, 'The ghetto of exclusion and the fortified enclave: New patterns in the United States', American Behavioral Scientist, 41:3 (1997).

${ }^{83}$ Blakely and Snyder, Fortress America; Karina Landman and Martin Schonteich, 'Urban fortresses', African Security Review, 11:4 (2002), pp. 71-85; Marcuse, 'The ghetto of exclusion'; Neznar Al-Sayyad and Ananya Roy, 'Medieval modernity: On citizenship and urbanism in a global era', Space and Polity, 10:1 (2006), pp. 1-20.
} 
intended to prevent penetration by non-residents'; ${ }^{84}$ the coordinated efforts to carve out 'a safe haven for the elites ${ }^{85}$ in response to increasing perceptions of crime and insecurity. That these 'safe havens' relied on regimes of surveillance and militarisation (for example, defensive architecture, CCTV, private security personnel) led to claims they were in fact part of 'an open social warfare ... against the welfare of the urban poor' ${ }^{86}$ Gated communities were used as comparative examples of forms of 'social segregation and defensive urban living ${ }^{87}$ that could be employed even by peacekeeping forces in postconflict scenarios.

Works navigated with ease from the image of the urban fortress to the image of imperial or neocolonial conquest and finally the template of the camp. For Edward J. Blakely and Mary Gail Snyder, the 'first' gated community in Britain was part of an imperial policy, built by Roman settlers circa $300 \mathrm{BC}^{88}$ Mbembe himself situate gated communities within the logics of colonial and late modern forms of 'splintering occupation' based on the 'control [of], surveillance and separation [from]' undesirable populations. ${ }^{89}$ It is his awareness of the logics of colonial occupations that takes him to the concept of the state of siege and the use of the exception as the generalised form of sovereignty, violence, and terror in modernity (in this case, with reference to the Palestinian context). And he is not alone in picturing gated communities along the lines of the exception. In a somewhat provocative statement, Bülent Diken goes as far as to describe gated communities as 'more "benevolent" camps', placing them in a spectrum of sites of demarcation and separation of the good life from the bare life. ${ }^{90}$

In the literature on gated communities, the themes of security and segregation are often discussed in the context of responses to the transformation of the global housing market under highpaced globalisation. To use Mike Davis's example, the metaphor of enclavisation as warfare is usually oriented by the question of social welfare. When David Harvey speaks of urban enclosures as a form of neocolonial expansion, he is situating them vis-à-vis wider processes of enclosure of the commons that characterised the turn of the century. ${ }^{91}$ Gated communities are part of processes of 'creative destruction' required by the capitalist imperative of growth at an everexpanding pace and the need to find fixes to idle capital in space; ${ }^{92}$ in this case, the creation of housing developments as a form of realising profits via the fencing off of public space. Importantly, depending on the stress scholars place on the themes of warfare or welfare, they open the space for rethinking or even rejecting the metaphor or the 'urban fortress'. Far from ending insecurity, the logic of enclavisation is seen as part of the problem, reinforcing patterns of urban violence by mobilising discourses of fear, criminality and hatred for 'marginal' elements of society (sometimes even in the absence of any real rise in crime).$^{93}$ The more one focuses on

\footnotetext{
${ }^{84}$ Blakely and Snyder, Fortress America, p. 2.

${ }^{85}$ Charlotte Lemanski, 'Everyday human (in)security: Rescaling for the southern city', Security Dialogue, 43:1 (2012), pp. $61-78$ (p. 68).

${ }^{86}$ Mike Davis, 'Fortress Los Angeles: The militarization of urban space', in Michael Sorkin (ed.), Variations on a Theme Park: The New American City and the End of Public Space (New York, NY: Hill and Wang, 1992), pp. 154-80 (p. 155).

${ }^{87}$ Mark Duffield, 'Risk-management and the fortified aid compound: Everyday life in post-interventionary society', Journal of Intervention and Statebuilding, 4:4 (2010), pp. 453-74 (p. 466).

${ }^{88}$ Blakely and Snyder, Fortress America, p. 11.

${ }^{89}$ Mbembe, Necropolitics, p. 81.

${ }^{90}$ Bülent Diken, 'From refugee camps to gated communities: Biopolitics and the end of the city', Citizenship Studies, 8:1 (2004), pp. 83-106 (p. 97).

${ }^{91}$ David Harvey, 'The right to the city', New Left Review, 53 (September/October 2008). For contrasting and apologetic view of gated communities as 'club goods' increasing efficiency and consumer satisfaction in a market economy, see Renaud Le Goix and Chris J. Webster, 'Gated communities', Geography Compass, 2:4 (2008), pp. 1189-214.

${ }^{92}$ David Harvey, 'Neoliberalism as creative destruction', Annals of the American Academy of Political and Social Science, 610:1 (2007), pp. 22-44.

${ }^{93}$ Teresa P. R. Caldeira, City of Walls: Crime, Segregation, and Citizenship in Sao Paulo (Berkley, CA: University of California Press, 2000); Setha M. Low, 'The edge and the center: Gated communities and the discourse of urban fear', American Anthropologist, 103:1 (2001), pp. 45-58; Sobia Ahmad Kaker, 'Enclaves, insecurity and violence in Karachi',
} 
the imperative of accumulation (as opposed to the promise of protection) the more they invite a rethinking of the bellicose language of CDT, revealing the very polysemic character of claims of 'security'. In the fierce neoliberal world, defined by the volatile mix of market deregulation plus a regime of currency fluctuation, gated communities appeared as more secure investments, assumed as they were to be hedged from the risks of financial crises and sudden devaluation. ${ }^{94}$

The move from warfare to welfare also clarifies how gated communities could work as templates for analysing wider sociopolitical phenomena. In their incisive critique of immigration policy in Europe, Henk van Houtum and Roos Pijpers interestingly 'evoke the image and representation of a gated community ${ }^{\text {'5 }}$ in opposition to the usual 'metaphor of a hermetically sealed "Fortress Europe". 96 Far from being completely segregated spaces, both communities rely on a contingency of bodies that 'slips through the maze ... and cater to the homes inside the community, sustaining the easy living. ${ }^{97}$ What is at stake here is nothing other than the meaning of segregation itself. While the emphasis on warfare tends to represent segregation as the physical separation of the undesirable other (reaching its climax in the image of the camp), I argue that a focus on welfare poses a more complicated relation: the fact that the other is always already inside the community borders, and not only in the necropolitical capacity of internal enemies, but as providers of vital services.

Despite promising a world of seclusion, the gated community can only survive and thrive by constantly accommodating those who they promise to 'keep outside'. Works on urban enclosures are well aware of this fact, always referring to the multitudes of service staff (the nannies, cleaners, chauffeurs, and private guards) who are subjected to strenuous commutes on a daily basis; those who, at the same time, must be pushed to the peripheries of the city (where they must live) and pulled back inside the gated communities (where they must work). What most accounts fail to see, however, is that this dual movement problematises descriptions of gated communities as micro-apartheid states. Even the most fervent enthusiast of their seclusive lifestyle is painfully aware that their easy life would collapse should the fantasy of complete segregation ever become a reality. The Covid-19 pandemic poses an eye-opening, if unfortunate, example. The fact that physical isolation was so fiercely opposed by so many precisely when it had become a clear health imperative should come as no surprise. Societies of segregation are also societies of enforced encounters. It is hard to miss the symbology of the case of federal states in Brazil where domestic work was legally classified as essential work, compelling maids to work on site during lockdown. ${ }^{98}$

It is from this fundamental observation of gated communities as sites of enforced encounters, between those who are catered for and those who cater, that our vision of the GC as a template of violence begins. The first assumption that requires rethinking is the presumed dispensability or disposability of the latter. The multitude of servants who provide the work required for the maintenance of the GC might seem disposable as individuals (by virtue of their numbers, each one of them could be easily replaced 'without loss'). But, from the perspective of their role, they are absolutely indispensable to the GC world. Walter Mignolo is all too aware of this slippage between the 'lives that are dispensable and as such they are either discarded or when necessary made in-dispensable as labor force and consumers', ${ }^{99}$ but he starts from the wrong end. The damnés

\footnotetext{
South Asian History and Culture, 5:1 (2014), pp. 93-107; Derek Hook and Michele Vrdoljak, 'Gated communities, heterotopia and a "rights" of privilege: A "heterotopology” of the South African security park', Geoforum, 33:2 (2002), pp. 195-219.

${ }^{94}$ Lemanski, 'Everyday human (in)security', p. 68.

${ }^{95}$ Henk van Houtum and Roos Pijpers, 'The European Union as a gated community: The two-faced border and immigration regime of the EU', Antipode, 39:2 (2007), pp. 291-309 (p. 292).

${ }^{96}$ Ibid., p. 292.

${ }^{97}$ Ibid., pp. 304-05.

${ }^{98}$ Randall, 'Domestic Workers and COVID-19'.

${ }^{99}$ Walter Mignolo, 'Dispensable and bare lives: Coloniality and the hidden political/economic agenda of modernity', Human Architecture: Journal of the Sociology of the Sociology of Self-Knowledge, 7:2 (2009), p. 76.
} 
are not first disposable and later made indispensable whenever necessary. Their indispensability, their objectified and commodified existence constitutes the cornerstones of the GC.

Second, the template of the GC also raises questions regarding the concept of the ego conquiro. The subjectivity of those who enjoy the community's easy life is much less imposing than the vision of a subject qua conqueror made in the image of God. The subject who openly accepts 'I couldn't manage without a maid ${ }^{\text {'00 }}$ is hardly dreaming of existing alone. GC patrons ${ }^{101}$ are often far from certain of their own ontological superiority; their sense of superiority vis-à-vis his non-others is always troubled, volatile, and uncertain, at times mediated by feelings of racial inferiority towards themselves. GC patrons can be said to lie in a non-equidistant middle ground between the ego conquiro and the damnés. The subjective place, to freely use Foucault's terminology, that constitutes a middle ground historically occupied by the global middle classes and the elites in the Global South (the national bourgeoisie, the compradorial class, and the Latin American creoles).

Third, and most importantly, the two forms of subjectivity share the lived experience of a certain alienation, translated here as disarrangement. The concept of disarrangement accepts that urban enclosures are situated in a much larger history of enclosures, processes of dispossession, and displacement that defined the birth of the modern economy. ${ }^{102}$ It is also an effort to go back to Quijano's conceptualisation of coloniality as articulated within the scope of capitalist social relations, something that is always acknowledged but not emphasised enough in CDT. Quijano's effort shares similarities with works on racial capitalism, suggesting a close link (if not a necessary connection) between processes of capital accumulation and the differentiation of human groups. ${ }^{103}$ Jodi Melamed summarises the relationship by stating that the antinomies of accumulation require loss, disposability, and the unequal differentiation of human value, and racism enshrines the inequalities'. ${ }^{104}$ This enshrining of inequalities, the mix between accumulation and differentiation, produces what I call a disarrangement in those dispossessed. Eduardo Galeano's summary of the fate of indigenous peoples in the Americas comes to mind: '[d]esterrados em sua propria terra, condenados ao êxodo eterno [uprooted in their own lands, condemned to an eternal exodus]'. ${ }^{105}$ We could equally think of the prominence of the concept exile (diaspora) in radical black thought, ${ }^{106}$ as illustrated by the words of Brazilian, pan-Africanist intellectual Abdias do Nascimento. Due to his opposition to the military regime on issues of racial discrimination and his role in the black movement, Nascimento was forced into exile in 1968. His testimony features in an edited volume published a decade later, where he makes the disconcerting comment that his exile did not commence in 1968, but on the day he

\footnotetext{
${ }^{100}$ Padmaja Barua, Anne Waldrop, and Haldis Haukanes, 'From benevolent maternalism to the market logic: Exploring discursive boundary making in domestic work relations in India', Critical Asian Studies, 49:4 (2017), pp. 481-500 (p. 494).

${ }^{101}$ I have chosen the word patron to refer to the subjectivity of homeowners in the GC for two main reasons. First, in the English language, patrons incorporate the meaning of clientele; patrons are consumers of services. Second, in many romance languages (such as Spanish, Portuguese, and French) the terms patrón/patrão/patron betray a class position (employers or proprietors) but also, sometimes, the sense of 'standard', or the normal quality against which things are measured.

${ }^{102}$ Aníbal Quijano and Immanuel Wallerstein, 'Americanity as a concept, or the Americas in the modern world system', International Social Science Journal, 134 (1992), pp. 583-91; Patrick Wolfe, Traces of History: Elementary Structures of Race (London, UK: Verso, 2016); Harvey, 'Neoliberalism as creative destruction'.

${ }^{103}$ Cedric J. Robinson, Black Marxism: The Making of the Black Radical Tradition (Chapel Hill, NC: The University of North Carolina Press, 2000); Jodi Melamed, 'Racial capitalism', Critical Ethnic Studies, 1:1 (2015), pp. 76-85; Gargi Bhattacharyya, Rethinking Racial Capitalism: Questions of Reproduction and Survival (Lanham, MD: Rowman \& Littlefield, 2018).

${ }^{104}$ Melamed, 'Racial capitalism', p. 77.

${ }^{105}$ Eduardo Galeano, As Veias Abertas da América Latina (Rio de Janeiro: Paz e Terra, 1982), p. 34, the author's translation.

${ }^{106}$ Robinson, Black Marxism; Mbembe, Critique of Black Reason; Paul Gilroy, The Black Atlantic: Modernity and Double Consciousness (London, UK: Verso, 1993).
} 
was born. ${ }^{107}$ This experience of life as exile (and not only life in exile) is at the basis of the concept of disarrangement.

Disarrangement is more than the experience of displacement; it also implies a sense of disorder. The link between exile and disorder is captured by Gloria Anzaldúa's claim that 'el exilio' equalled living 'separated from our identity and our history'. ${ }^{108}$ Disarrangement upsets the racialised geopolitics of coloniality, transgressing the pillars of a nation-state system based on the conflation of ethnicity and territory. But this is not something that can be solved by a crude call to nativism, it is something already dictated by the order of coloniality. It is not one's birthplace, but 'race [that] denotes certain people as being out of place'. ${ }^{109}$ To live life in disarrangement (as out of place) is to become the embodiment of impurity, defilement and corruption, in the sense of Mary Douglas's seminal view of 'dirt as matter out of place'. ${ }^{110}$ The association between race and regimes of purity and impurity, including colonial fears of contagion and racial mixing, has been widely documented. ${ }^{111}$ A disarranged existence is perceived as being, in itself, transgressive (subversive) of the sociopolitical codes that seek to anchor the M/CW in a certain order and stability. Their presence stands for a sign of corruption.

But the indispensability of the racialised workforce in the GC forces us to add a caveat here, putting emphasis on the word 'perceived'. The proclaimed dehumanisation of the damnés (or the gated community servants) should be taken for what it is: not a statement of fact, but an announcement that produces relations of subordination (creating the very reality it represents). As the sine qua non condition for the (re)production of easy life, the racialised workforce must be misrepresented as being in the wrong place precisely where their being (presence) is essential. It is the fact that they are the right people in the right place that dehumanising practices seeks to conceal.

But disarrangement is not a one-way street; it also speaks to the forms of misrecognition and alienation so clearly outlined in Fanon's Black Skin, White Masks. There, colonial dispossession is examined not only as a system of oppression and domination, but also as a psychopathology, robbing the colonised of their very sense of self worth. ${ }^{112}$ The damnés who are born into a racist order silently introject the misrepresentation of themselves as beings out of their place. This disarrangement is masterfully captured by two anecdotes: the black Martinican child who worships Tarzan (the white hero) but is regarded as closer to his dark-skinned enemies in the eyes of the white world; and the French child who, upon sight of Fanon's black body, shouts 'Mama, see the Negro! I'm frightened!' ${ }^{13}$ Both anecdotes convey a painful and complex form of alienation: the experience of those who misrecognise themselves as belonging to a world that insists on misrepresenting them as out of place. It is through this painful experience that colonisation acquires its traumatic contours. Each encounter with the coloniser produces violent crashes between misrecognition and misrepresentation that, in Fanon's words, 'flung back in my face like a slap'. ${ }^{114}$ Each racial slur, inappropriate joke, and impromptu comment (such as the child's) is somatised as proper physical wounds, carving out the racial regime (the colonial wound) in the flesh of the colonised. From the perspective of the colonial totality, they appear as efforts to correct the

\footnotetext{
${ }^{107}$ Pedro Celso Uchôa Cavalcanti and Jovelino Ramos, Memórias do Exílio, Brasil 1964-19??: De Muios Caminhos (São Paulo: Editora Arcadia, 1978), p. 23.

${ }^{108}$ Anzaldúa, Borderlands/La Frontera, pp. 7-8.

${ }^{109}$ Wolfe, 'Traces of history', p. 17.

${ }^{110}$ Mary Douglas, Purity and Danger: An Analysis of Concepts of Pollution and Taboo (New York, NY: Routledge, 2001), p. 36.

${ }^{111}$ Anna Laura Stoler, Race and the Education of Desire: Foucault's History of Sexuality and the Colonial Order of Things (Durham, NC and London, UK: Duke University Press, 1995); Maria Lugones, 'Purity, impurity, and separation', Signs, 19:2 (1994), pp. 458-79.

${ }^{112}$ Ashis Nandy, The Intimate Enemy: Loss and Recovery of Self under Colonialism (Delhi: Open University Press, 1983).

${ }^{113}$ Fanon, Black Skin, White Masks, p. 85.

${ }^{114}$ Ibid.
} 
misrecognition of the damnés by putting them back in their place. ${ }^{115}$ But the damnés' location matter little here. Their place can only be an unescapable out of place.

The GC suggests that this sense of disarrangement can also be found in an unlikely place. My contention is that a closer look at the subjectivity of GC patrons points us towards a different sense of alienation that escapes a phenomenology of life under conditions of oppression. And perhaps no historical figure is better suited to clarify this particular experience of alienation than those historically constituted as subjects at the juncture of the Latin and American world. Contrary to Anglophone view of Latin Americans as non-Westerners, Latin American history is filled with melancholic longings expressing a patrilineal affinity with Europe: ${ }^{116}$ 'todos somos descendientes de europeos [We are all descendants of Europeans]'; 17 'somos los hijos de los emigrantes que salieron de Europa para hacer su Nuevo Mundo [We are the children of the immigrants who left Europe in order to make a New World]'; ${ }^{18}$ 'nuestros padres europeos [our European parents]. ${ }^{119}$ In these laments we encounter premium beneficiaries of brutal systems of exploitation who also felt the need to claim: 'somos ainda hoje uns desterrados em nossa terra [we still are, to these days, exiled in our land]'. ${ }^{120}$ We could hear this melancholy in two ways: either as the simple statement of a historical fact, or as attempts to erase the role of non-Europeans in the constitution of Latin American republics. But I suggest another path: reading them, via Fanon, as the registers of a sense of disarrangement related to the experience of life fora de lugar [out of place]. ${ }^{121}$

The split between misrecognition and misrepresentation is also constitutive of the lived experience and subjectivity of the GC patrón/patrão. While enjoying privileges of the easy life at home, they are made painfully aware of their own underdevelopment everywhere they go; ${ }^{122}$ the backwardness that stands as an eternal measure of the immense abyss separating Latin Americans from the divinity they worship (the European dream). And it is at the level of a dream, in the sense proposed by Freud, that their relationship with Europe is mediated by a series of wishfulfilling mechanism: ${ }^{123}$ we could interpret the elevation of dual citizenship as a sign of social status, the seasonal trips to the 'motherland' (or Disneyland) and the otherwise unfathomable fascination with department stores in Miami, as signs of this worshiping. Needless to say, such reverence is, for the most part, unreciprocated. The patrón/patrão is always at risk of waking up from their dreams by the sound of 'Mama, see the Latino! I'm frightened!'

There are many reasons to take this Latin American experience of disarrangement as the sign of a more generalisable trend. The fact that Fanon's critique, based on the French-Martinican experience, powerfully resonated throughout the world in different contexts, is one such reason. ${ }^{124}$ Another is that we find very similar claims concerning alleged ties of filiation with the

\footnotetext{
${ }^{115}$ Kilomba, Memórias Da Plantação.

${ }^{116}$ Mignolo, The Idea of Latin America.

${ }^{117}$ 'Macri y su explicación para la alianza con la UE: En Sudamérica todos somos descendientes de europeos’, Página 12, availabe at: \{https://www.pagina12.com.ar/91480-en-sudamerica-todos-somos-descendientes-de-europeos. $\}$ accessed 24 June 2019.

${ }^{118}$ Cited in Dussel, 1492: El encubrimiento del otro, fn. 20.

${ }^{119}$ José Vasconcelos, La raza cósmica: Misión de la raza iberoamericana (Buenos Aires: Espasa-Calpe, 1925), p. 48.

${ }^{120}$ Sérgio Buarque de Holanda, Raízes do Brasil (São Paulo: Companhia das Letras, 2004), p. 31.

${ }^{121}$ The concept of fora de lugar/out of place (initially used to criticise the adoption of liberal ideas in the Brazilian slave society) has acquired a privileged place in theorisations of the Latin American and other postcolonial conditions. See Walter Mignolo, 'Decires Fuera de Lugar: Sujetos Dicentes, Roles Sociales y Formas de Inscripcion', Revista de Critica Literaria Latinoamericana, 21:41 (1995), pp. 9-31; Roberto Schawrz, Ao Vencetor as Batatas: Forma Literária e Processo Social nos Inícios do Romance Brasileiro (São Paulo: Duas Cidades, 1992); Imre Szeman, 'Belated or isochronic?: Canadian writing, time and globalization', Essays on Canadian Writing, 71 (2000), pp. 186-94.

${ }^{122}$ Aníbal Quijano, 'El fantasma del desarrollo en América Latina', Revista Del CESLA, 1 (1998), pp. 38-55.

${ }^{123}$ Sigmund Freud, The Complete Psychological Works of Sigmund Freud, Vol. IV (London, UK: Vintage Books, 2001).

${ }^{124} \mathrm{Mbembe}$ himself is a good example of the generalisability of the Fanonian school. For others, see Glen Sean Coulthard, Red Skin, White Masks: Rejecting the Colonial Politics of Recognition (Minneapolis, MN: University of Minnesota Press, 2014); Homi K. Bhabha, The Location of Culture (London and New York: Routledge, 2004); Nandy, The Intimate Enemy.
} 
conquistadores beyond the Latin American context. I propose to read those claims as expressing a meaning closer to Tzvetan Todorov's statement that 'We are all the direct descents of Columbus, it is with him that our genealogy [the modern world] begins. ${ }^{125}$ In other words, not as a question of lines of descent (filiation) but as an affirmation of an individual's subject position in the order of the world (affiliation). And it is fair to say that this Latin American disarrangement could also be experienced by whoever happens to claim a similar affiliation in the order of coloniality: those we could dub white, but not quite (or, not without a hint of irony, ego conquiro ma non troppo).

The literature on gated communities is of great help here. Gated communities do not only serve the demand for idiosyncratic lifestyle choices. They also serve demands for 'a world clearly distinguishable from the surrounding city'. ${ }^{126}$ Richard Ballard situates the rise of gated communities in South Africa as a silent continuation of the Verwoerdian 'diabolical project of creating Europe in Africa'. ${ }^{127}$ Once apartheid ended, security villages became spaces of semigration (a mix of partial immigration and segregation) of whites longing for a lost 'Western, modern, sense of self ${ }^{128}$ in the wake of democratic transition. In a similar vein, Derek Hook and Michele Vrdoljak explain the walls of the South African security parks as efforts to inscribe spatial and symbolic discontinuity in the fabrics of society. The security village constitutes 'specific social spaces whose social meaning is out of place and unsettling within a geographical relationship of sites' ${ }^{129}$ We hear echoes of such discontinuity in the Europeanised names attributed to gated communities throughout the Global South. Example such as the Place des Vosge (originally a Parisian square) and Alphaville complexes in Brazil (named after the ultra-futuristic city of Godard's 1965 film), ${ }^{130}$ the Lodha Belissimo condominium in Mumbai, ${ }^{131}$ and the Heritage Park villa in the outskirts of Cape Town, present more of less overt suggestions of affiliation with whiteness/Europe/modernity/the 'true' fatherland. They underscore a certain longing for the European/cosmopolitan dream that, in remaining elusive, must be desperately congealed in the very materiality of homes made of 'Italian marble, Spanish wooden flooring, German bath designs'. 132

Since this spatial discontinuity is not a given, the 'global' must be fabricated on a daily basis through the creative destruction of the 'local'. Zones must be cleared, people evicted, and public spaces must be ravenously swallowed by private developers, this much is known. What is often forgotten is that the making of easy living, 'a life of total and secure leisure', ${ }^{133}$ rests on a paradox of (in)convenience: the more the world of the GC expands, the more value it accumulates by maximising convenience, the more it is forced to face the inconvenient presence of racialised bodies inside the gates. The easier the easy life becomes, the harder it is for patrons to keep the indispensability of service staff as a 'repressed' reality. The presence of 'outsiders' inside the gates is both the convenient condition for the realisation of the European dream and the reality shock that crushes the community's dreamwork; it stands as a reminder that space remains, after all, continuous and that the GC, far from being a purified space, is built on a this 'structural corruption'.

\footnotetext{
${ }^{125}$ Tzvetan Todorov, The Conquest of America: The Question of the Other (Norman, OK: University of Oklahoma Press), p. 5.

${ }^{126}$ Caldeira, City of Walls, p. 265.

${ }^{127}$ Richard Ballard, 'Assimilation, emigration, semigration, and integration: "White" peoples' strategies for finding a comfort zone in post-apartheid South Africa', in Natasha Distiller and Melissa Steyn (eds), Under Construction: 'Race' and Identity in South Africa Today (Johannesburg: Heinemann, 2004), p. 54.

${ }^{128}$ Ballard, 'Assimilation, emigration, semigration, and integration', p. 51.

${ }^{129}$ Hetherington cited in Hook and Vrdoljak, 'Gated communities, heterotopia and a "rights" of privilege', p. 207.

${ }^{130}$ Perhaps the fact escaped the developers, perhaps it did not, but Godard's Alphaville is a dictatorship.

${ }^{131}$ Dhara Patel, 'The evolution of elite high-rise condominiums in India: From the global to the neo-colonial?', Postcolonial Studies, 20:4 (2017), pp. 456-78.

${ }^{132}$ Patel, 'The evolution of elite high-rise condominiums in India', p. 473.

${ }^{133}$ Caldeira, City of Walls, p. 265.
} 
The imperative of accumulation (the maximisation of convenience) therefore, sets in motion $a$ dialects of disarrangement whereby accumulation can never truly resolve the patron's (in)convenience. In vain, the everyday life in the GC is organised around a series of techniques to ensure the vital presence of the damnés is never 'misunderstood' as a sign of belonging. Servants (and visitors) must abide by a clear set of codes of conduct and rules of prohibitions, reinforced ever more so in times of expansion (when the presence of service staff increases). They include, for example, different lunch breaks, segregated lifts and staircases, bedrooms, service areas, and bathrooms. The fact that segregated spaces (meant to keep people apart) are often located side-by-side ${ }^{134}$ poses no paradox. In the GC, segregation works as a proclamation of difference in proximity; the closer and more visible segregated spaces are to non-segregated areas, the clearer their message.

The paradox of (in)convenience also resignifies the meaning of insecurity. In the GC, the outspoken fear of the barbarian outside the gates must be read as something more than the signs of misanthropic scepticism. This fear must be contrasted with a more fundamental, terrifying fear that only a life in proximity with their service staff can reveal: the disclosure of 'the ultimate secret of any social order, the pure and simple equality of anyone and everyone'. ${ }^{135}$ Nothing is more unsettling to the GC world than this inescapable Rancièrian equality of all subjects of speech (logos). Proximity does not reveal the damnés' lack of humanity, but, on the contrary, their unquestionable equality; the realisation that those following orders must be able to understand them; and if they do, there is no obvious reason why they should be the ones following orders. Equality has this double function in the GC: it is equality, and not difference, that haunts the encounter between patrons and servants; and it is also equality that provides hope for a different world, giving revolutionary contours to the most banal of interactions.

This fear caused by proximity (the relationship between humans) also spills over the sphere of proxemia (the relationship between humans and things). ${ }^{136}$ Those who fear the mere realisation of equality (in a political but also epistemological sense) are also anxious about the presence of those who do not belong (the dispossessed) so close to their belongings (possessions). In the GC, property is not only a tangible, secure investment, but also a secure foundation for the material and symbolic manufacturing of inequality. Here we see the coalescing of the categories of race and class in the GC, constituting the near perfect commutability between cultural (whiteness) and material (wealth) capital. ${ }^{137}$ In the GC, all attempts to distinguish between infra- and superstructure are highly arbitrary, ${ }^{138}$ both whiteness (Europeanness/cosmopolitanism) and ownership are part of the same logic of differenciation. ${ }^{139}$ This is why any policy of redistribution through consumption will face the ire of the GC and patrons will scorn at the mere possibility of 'maids visiting Disneyland'. ${ }^{140}$ It is also why the pettiest of crimes against property (theft or vandalism) are so often treated on par with the most gruesome crimes against persons (murder).

The violence of this dialectics of disarrangement differs from the concepts of necropolitics and the slippage of the ego conquiro into an ego extermino. The GC does not take the genocidal act as the measure of all violence, or paint violence as a primarily destructive force. In the GC, violence appears as inherently (re)creational element, in the sense that it provides the conditions for the reproduction of easy life and is also part of an economy of leisure delineated with contours of cruelty. Even when patrons nurture the fascist fantasy of racial/criminal purification, the

\footnotetext{
${ }^{134}$ Caldeira, City of Walls.

${ }^{135}$ Jacques Rancière, Disagreement: Politics and Philosophy (Minneapolis, MN: University of Minnesota Press, 1998 ), p. 30.

${ }^{136}$ Dussel, Filosofía de la Liberación.

${ }^{137}$ Castro-Gómez, La hybris del punto cero.

${ }^{138}$ Fanon, The Wretched of the Earth.

${ }^{139}$ Castro-Gómez, La hybris del punto cero.

${ }^{140}$ This lament was recently voiced by Paulo Guedes, the Minister of the Econmy of Bolsonaro's neo-fascist government See Luis Barrucho and Ricardo Senra, 'Empregadas na Disney? Viagem internacional foi item mais raro no auge do consumo da nova classe média', available at: \{https://www.bbc.com/portuguese/brasil-51476199\} accessed 25 November 2020.
} 


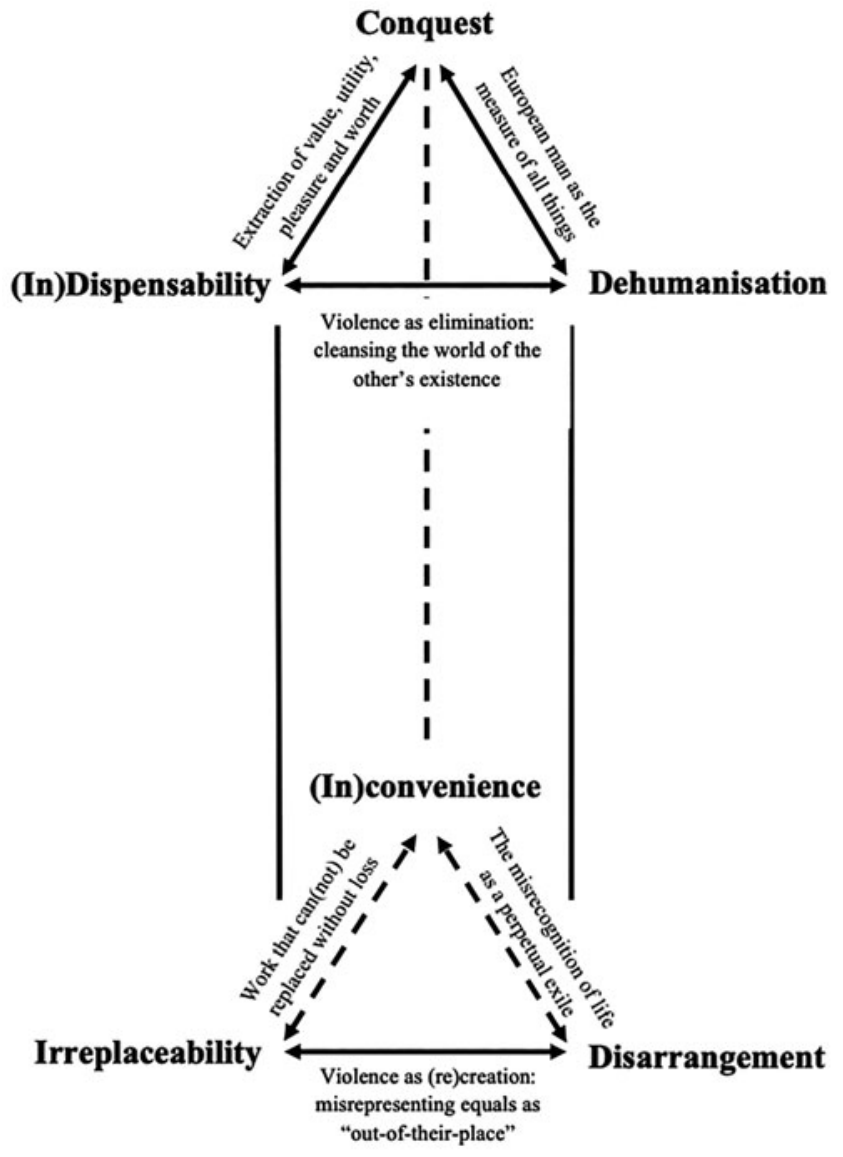

Figure 2. The prism of the gated community.

imperative of accumulation dictates otherwise, that is, they cannot afford to enact their fantasy. This is not to deny the reality of death and so-called disposability in the GC, but to read them always in relation to the assumption of irreplaceability. We could take Balibar's cue that the proletarian condition is characterised by insecurity ${ }^{141}$ and read the damnés 'constant encounter with violence and death' ${ }^{142}$ as but another expression of the 'class/race formation': the fabrication/disciplining of bodies who must be worked to death. Once again, the Covid-19 crisis provides the stark, but nonetheless illustrative examples of so many who, like Gonçalves, lost their lives not by virtue of being disposable, but in the capacity of essential workers.

The GC problematises the assumption that 'the remedy for a people being out of place is, after all, ethnic cleansing. ${ }^{143}$ Instead it highlights cases where 'white supremacy ... is not an eliminationist project and cannot afford to be'. ${ }^{144}$ If we were to keep the metaphor of dirt or refuse in our theorisation of violence, we should better join Rita Laura Segato in her portrayal of violence as a recycling plant: ${ }^{145}$ not a final solution, but a continuous response to continuously produced experiences of disarrangement; not as an endless war, but the endless misrepresentation of equality for

\footnotetext{
${ }^{141}$ Étienne Balibar, Masses, Classes, Ideas (New York, NY: Routledge, 1994).

${ }^{142}$ Maldonado-Torres, 'On the coloniality of being', p. 249.

${ }^{143}$ Wolfe, 'Traces of history', p. 17.

${ }^{144}$ Bhattacharyya, Rethinking Racial Capitalism, p. 115.

${ }^{145}$ Rita Laura Segato, Las estructuras elementares de la violencia: Ensayos sobre género entre la antropología, el psicoanálisis $y$ los derechos humanos (Buenos Aires: Prometeo Libros, 2010), p. 17.
} 
the (re)creation of white/cosmopolitan/European Man. It is important to note, however, that this particular concept of violence does not exhaust all possible conceptualisations of the phenomenon. As Figure 2 shows, the point of the GC is not to deny the logics of elimination altogether, which would be nonsense. The point is to further the critical commitment to anchor modernity's 'genocidal' drives in the everyday (in the 'recycling plants' of enforced encounters) without conflating the everyday with an endless state of exception or a neverending war.

\section{Conclusion}

In this article, I offer a conceptualisation of violence that pushes the boundaries of CDT, combining insights from the literature on racial capitalism and post-Marxist critiques. Informed by the critical literature on urban enclosures, I proposed to shift from the language of warfare predominant in the field to a language of welfare, taking the GC (instead of the camp) and its life of convenience (instead of conquest) as the templates for a decolonial critique of violence. The picture that emerges from this new template points towards a vision of violence as (re)creational and not an eliminationist project. The GC is home to fragile subjectivities whose consumption of the easy life (a life where convenience is maximised) is dependent on the indispensable presence of servants in close proximity to their superiors. Violence dictates these forced encounters between disarrange subjectivities, as the efforts to repress the obvious equality (not difference) between patrons and servants as subjects of speech by misrepresenting them as out of their place where they are most necessary. This violence is recreational in the senses that it constantly fabricates (colonial) difference where there is none, paving the way for the continuation of the modern/colonial order. But it is also recreational because it observes, as its ultimate end goal, the imperative for the accumulation of conveniences and the maintenance of leisurely life inside the GC walls.

Acknowledgements. I am grateful to Emmy Eklundh, Olivia Rutazibwa, and the anonymous reviewers for their invaluable comments on earlier versions of this work. I also extend my gratitude to Emma Brännlund for her vital tips and to the editorial team. Last but certainly not least, I would like to thank my newborn son Victor for his commendable behaviour during the final revisions. Needless to say, all remaining faults of this work are my own.

Henrique Tavares Furtado is a Senior Lecturer in Politics and IR in the Department of Social Sciences at the University of the West of England. His research lies at the intersection of the fields of political violence, critical security studies, transitional justice, memory and trauma studies, and poststructuralist and decolonial theories.

Cite this article: Tavares Furtado, H. 2022. Confronting the gated community: Towards a decolonial critique of violence beyond the paradigm of war. Review of International Studies 48, 91-110. https://doi.org/10.1017/S026021052100022X 